\title{
Reading the Archives of the Illicit: Gender, Labour, and Race in Helen McGowan's Motor City Madam
}

\section{Holly Marie Karibo}

In 1927, sixteen-year-old Mae Abshier arrived in Detroit, Michigan. The city was to become an adopted home, the final stop on a tumultuous journey that took her from the rural South to the industrial Midwest. Like thousands of people who migrated to the Motor City, she came to Detroit in search of work. And like many women on the move, Mae would find it not in the thriving industrial jobs that were the city's namesake, but in illicit industries that also flourished in the urban heartland. Changing her name to Helen McGowan, she entered the city's sex trade, operating as a prostitute and madam for the next thirty years. What separates McGowan's story from the many women who found employment through illicit means is that it has survived at all. In 1964, McGowan published her autobiography, Motor City Madam. ${ }^{1}$ Without this record, her story—like so many others—-would likely have faded from historical memory.

This article examines the gender, labour, and racial politics that emerge in McGowan's telling of her personal history. Using Motor City Madam as a case study, it traces the ways in which the author constructs her past and how it sheds light on women's lived experiences in the city's sex trade. In order to do so, this article places the genre of autobiography at the centre of its analysis. As Jennifer Jensen Wallach argues, autobiography is a unique form of writing that purports "to be both literature and history but is not entirely one or the other." This uneasy blurring of disciplinary lines has long led historians to debate the role that such texts should play in shaping the historical record. Many within the profession have acted with skepticism, seeing them as potential distortions that obfuscate "objective truth." For historians whose subjects are often absent from official historical records, though — and particularly for historians of the illicit—autobiographies can provide a layer of textural complexity that helps us understand what is so often rendered invisible: the subjective experiences of those who perform unsanctioned forms of labour. By drawing on the work of feminist literary scholars, who emphasize the importance of intention, rhetorical choice, and subjectivity in autobiographies, this article pushes historians to move beyond the strict letter of the text in order to trace how female writers actively reconstruct their own historical experiences. From this perspective, it examines Motor City Madam as an example of what James Barrett and David Roediger term "working-class autobiography," an individual introspection that provides insight into what historians often study from the perspective of the community. ${ }^{3}$

The history of labour in Detroit has a deep and rich historical tradition, 
one centred on the auto industry, male workers, and labour unions. Studies of female employment have also tended to focus on formal forms of work, leaving women's labour in Detroit's illicit economies underexplored. ${ }^{4}$ Yet, as Helen McGowan's story makes clear, informal and illegal forms of labour played important roles in workingclass communities throughout the city's recent past. As the only memoir published by a woman who worked in the city's sex trade, Motor City Madam provides a unique opportunity to analyze the politics of illicit labour as it evolved in the industrial city between the 1920s and 1960s. It also contributes to the growing body of scholarship that seeks to uncover the central role that gender and sexual codes played in shaping working-class communities — and the experiences of working-class women-during the mid-twentieth century. ${ }^{5}$

Rather than presenting a voyeuristic look into the life of a "woman of pleasure," Motor City Madam reads as a labour history, a story about one woman's efforts to survive and succeed in the urban underworld. McGowan takes illicit labour seriously, framing it as closely integrated into larger working-class communities that developed in the industrial Midwest. Her memoir both uncovers the social history of vice economies and provides pointed critiques of the sex/gender system that made women's work difficult and dangerous. In tracing her own history, McGowan anticipates recent arguments made by feminist scholars and activists who have worked to legitimize sexual labour and to push for improved working conditions for the women that perform it. Drawing on the concept of "sex work," scholars like Ine Vanwesenbeeck, Melinda Chateauvert, and Kamala Kempadoo have argued that criminalization endangers the lives of women who make a living in the sex trade, and makes the practice "less likely to be workercontrolled, non-abusive, and non-exploitative." ${ }^{\prime 6}$ Decades before these critiques emerged in formal forums, McGowan details the many problems that criminalization regimes brought for working women. In doing so, her text provides a proto-feminist argument in defence of women's sexual labour at a time in which vice laws remained strictly intact. ${ }^{7}$

McGowan also provides important insight into the complex and contradictory ways that race shaped Detroit's vice economies. On the one hand, McGowan's experiences make clear that racial and ethnic divisions emerging within the formal economy between the 1920s and 1960s also affected informal forms of labour. White women and men often worked at higher levels of illicit trades, a reality reflected in McGowan's own ability to rise to the status of madam. In the increasingly segregated city, whiteness itself became a marketable commodity, one that defined a woman's value in the illicit industry. Yet, though McGowan was able to capitalize on the racial dynamics that shaped the city's vice districts, she also develops explicit critiques of that emerging racial order. A close reading of her narrative demonstrates that McGowan understood marginality as rooted in several interrelated sources. For women and men working in the city's vice districts, racial markers, class status, and gender often functioned in tandem to determine their ability to 
succeed in the city's vice networks.

A close analysis of Motor City Madam allows us to examine the complex subjectivity McGowan expresses in what might otherwise be dismissed as simply a sensational "tell-all" on prostitution. More broadly, this essay examines the ways in which autobiographies can illuminate the archives of the illicit. It is an exercise in tracing the formation of a working-class consciousness in a decidedly illicit economy, and in rethinking the gender and racial politics that we read in working women's memoirs. In foregrounding the ways in which McGowan's position as a madam-and as a working-class white woman-shaped the narrative, we gain important insight into labour systems, gender politics, and a burgeoning feminist critique at mid-century.

\section{Autobiography, Archives, and the Politics of Memory}

While the study of prostitution has a long genealogy, the rise of the history of sexuality as a viable field has opened up new ways to study its meanings. Early North American research tended to focus on uncovering the sensational history of the trade or on efforts to regulate and suppress it. ${ }^{8}$ The emergence of social and women's history, with their emphasis on history from the bottom up, pushed scholars to examine the sex trade through a more critical lens. Much of the research that has emerged since the 1980s has focused on the late-nineteenth and earlytwentieth centuries, examining prostitution as a form of labour in urban centres and on the Western frontier. ${ }^{9}$ Despite this large volume of work, the question of how to access the lived experiences of working women remains a challenge. Since the history of prostitution exists most readily at the juncture of labour history and the history of sexuality, it shares the fields' focus on perspectives that are often difficult to locate in traditional archives. Much of the relevant primary evidence consists of records created by the very agencies and organizations tasked with suppressing prostitution-police, courts, social workers, and religious organizations_-rather than by workers themselves. ${ }^{10}$

Within this context, autobiographies might seem like one clear solution to archival silences. Yet, like the broader discipline of history, vice historians have also been reluctant to draw on these texts. Some scholars have questioned their authenticity, noting the likelihood that they were "written as moralistic tracts by 'purity crusaders' who wished to advance their anti-prostitution movement." 11 Even when they are deemed authentic, historians have remained skeptical. As Timothy Gilfoyle argues,

The few autobiographies of prostitutes ... are of questionable value. These are usually by prosperous madams, hardly representative of the common or occasional prostitute's experience. Some authors romanticize the entire practice of prostitution. Many accounts were probably edited to remove 
controversial and unsavory subjects. And most were published for profit, not to reveal truth. ${ }^{12}$

While Gilfoyle raises important methodological cautions, feminist literary scholars provide important insight into how to address these issues. Their work stresses that the ways in which women construct, remember, and retell their histories are central to a critical understanding of autobiographies. The texts do not provide unmediated insight into a supposed collective "female" past, but rather require careful attention to the historical location of the writer, the issue of memory and nostalgia, and an understanding of the intentions behind the text. ${ }^{13}$ Barrett and Roediger similarly argue that scholars usually treat personal narratives as empirical studies, and instead need to read them "with working-class subjectivities in mind," paying careful attention to "personal identity, relationships, and emotional responses to life experiences." In reading a literary text from a historical perspective, then, the goal is not to uncover some inherent Truth behind each particular event; nor is it to try to delineate a clear line between fact and fiction. Instead, scholars should take seriously how the writer actively frames her own past, what she chooses to include, and the language she uses to convey her message. In this formulation, the day-to-day becomes less important than the ways in which McGowan actively constructs her identity as a proto-feminist, as a working-class woman, and as a sex worker.

The significance of Motor City Madam also stems from the historical moment in which it emerged. Since the mid-nineteenth century, laws solidified under Anthony Comstock's crusade against the illicit had prevented the publication and distribution of "pornographic" materials and a wide range of literature. ${ }^{15}$ This included attempts to publish prostitutes' accounts that did not fit with a moralistic "fallen woman" narrative. ${ }^{16}$ In the 1950 s and 1960 s, such draconian publication codes began to crumble, as writers stifled by the oppressive atmosphere of the Cold War mounted legal challenges that chipped away at obscenity laws. ${ }^{17}$ Publications expanded beyond the genre of pulp fiction, providing more graphic depictions of sexuality, drugs, and other previously banned topics. ${ }^{18}$

New York City-based Pageant Press was able to capitalize on these loosening restrictions. ${ }^{19}$ Alongside Exposition and Vantage, Pageant was one of the largest subsidy presses in the US during the postwar years. It would eventually print about 5,000 copies of Motor City Madam over two editions. It is unclear how Helen McGowan connected with her literary consultant, Norman Edelmann, or whether she had to pay to publish her autobiography (as was common with vanity presses). Her story, though, fit with the press's interest in non-fiction historical accounts that could also provide the thrill of a pulp novel. Using sensationalism to attract a broad readership, the original back jacket described the text as "a shocking and important book ... which should be read by ministers, police officials, and citizens concerned with the future of our community life." ${ }^{20}$ In the opening dedication, the author similarly promised readers that, "newspapers, pulp paper magazines, television, and 
movies have combined to present a false picture of the world I live in. The facts as I see them may sometimes be too sordid for your liking, but they are true." ${ }^{21}$ In this way, the book blended the opportunity for a newly salacious writing style with a claim to authority and documentation.

The publication of Motor City Madam in the mid-1960s also reflects an emerging readership interested in the experiences of writing from a "woman's perspective." In this context, feminist writers began to reformulate notions of womanhood that would upset male-centred paradigms in American literature (and beyond). Yet, as materialist feminists have since made clear, these ideals often reified a biological-determinism that privileged white, middle-class norms and obscured the ways that the category "woman" itself was a political construct. ${ }^{22}$ As Christy Rishoi argues, "the budding mainstream feminist movement often failed to be inclusive in its explicit valorisation of women's experience, and left it open to a wide-ranging critique by women of colour, poor women, and lesbians." ${ }^{23}$ The fact that McGowan's text was published within one year of Betty Friedan's The Feminine Mystique - the book that helped launch Second Wave Feminism-suggests that alternative voices were already emerging and fighting for space in the public discussion. ${ }^{24}$ Unlike Friedan, McGowan claims to speak as a woman working on the margins of America's industrial cities. Through her discussion of issues like labour, poverty, and inequality, she provides the perspective of a woman whose experiences fell far outside the mainstream feminist movement, yet who nonetheless developed an (at times radical) political critique of the sex/gender system at midcentury.

\section{Narrating the Early Years}

McGowan presents her story in chronological order, returning periodically to what she frames as formative moments in her youth. The first chapters read as a comingof-age story that explains how McGowan found herself on the streets of Detroit-a far cry from her childhood upbringing. McGowan was born on January 23, 1911, in Malden, a small country town in southeastern Missouri. She describes herself as a "lowdown Southerner," the daughter of poor sharecroppers of mixed Anglo and Cherokee descent. ${ }^{25}$ Her parents were church-going folk who raised her in a home of "poverty and honesty." 26 Yet, early on McGowan was determined to become something more than just a sharecropper's wife. Some of her fondest memories were of the many times she snuck away from the fields to read novels at the public library. Though forced to leave school at the age of twelve, McGowan found solace in the adventures and freedom she experienced in the tales she read when not under her parents' watchful eyes. ${ }^{27}$ "My father wore out many switches on Robinson Crusoe, The Sea World, and Little Women," she explained. "Work and pray,' he would tell me. 'God sees everything'." Though her parents were attempting to save her from "eternal damnation," she concluded that she "could have stood a little more of hell and a little less of beating." 28 
Several interrelated events convinced McGowan at an early age that women held a subordinate status in American society. When she became pregnant by a local farm boy at age fifteen, her parents beat her unconscious and forced her to marry the eighteen-year-old father of the baby. Shortly after the shotgun wedding, he took a train out of town and she never heard from him again. Seeking to avoid the gossip that quickly developed in Malden, her parents kicked her out of their house. Young, pregnant, with nowhere to turn, McGowan ended up on the doorstep of an African American woman who lived on a farm outside of town. Ruth took McGowan in, offering her food and a place to stay. McGowan credits Ruth with helping to explain the sexual double standard to her, a social norm that punished women for sexual transgressions while condoning the same behaviour by men. "Never you mind," Ruth told the distraught girl, "the ways of this world is strange. When a girl makes a mistake, they knocks her down for it. When a boy does it, all they say is boys will be boys. It ain't fair but that's what happens. You jus' got to get used to it." Every night after, McGowan prayed, “Oh Lord ... don't make my baby a girl. A boy has more chance to be happy. I don't want my baby to be like me."29

After only four days at Ruth's house, McGowan's mother showed up and berated her for humiliating the family in another way: crossing the colour line. "You ought to be ashamed of yourself, stayin' with niggers," she scolded. "What have I done to deserve a daughter like you?" 30 The hypocrisy was not lost on McGowan: "My mother was ashamed that her daughter was living with negroes. Malden was a small town and gossip was the chief entertainment. It was right and proper for my mother to turn me out of my home but wrong to take shelter with colored people." 31 By the 1920s, Missouri-like other Southern states-had enacted Jim Crow laws that attempted to enforce strict racial segregation in everything from education to public accommodations. ${ }^{32}$ In an environment where interracial interactions in public and private were highly codified, her mother's fears came to fruition. When McGowan's baby boy was born, rumours spread that he was "darkskinned." The shame of the supposed interracial relationship became so overwhelming that McGowan's mother sent her to live with her sister Rita in Flint, Michigan. "I would not stay in Malden," McGowan declared. "I could not stay in the South ... I had to leave."33 We never hear what became of McGowan's son, but the resentment she experienced because of her alienation from her family reemerges in her critiques of the sex/gender system.

Personal struggles, community pressure, and family conflict clearly shaped McGowan's move north. Her experience, though, also represents larger patterns of work, labour, and migration emerging in the first decades of the twentieth century. With the expansion of the auto industry, cities in the Great Lakes region began to attract workers from across the country and the world. As production ramped up during the First World War, thousands of workers moved to cities like Detroit, Chicago, Cleveland, and Flint in search of gainful employment. By the 1920s, Flint was home to more General Motors workers than any other city in the world. ${ }^{34} \mathrm{It}$ 
was, in the words of one historian, a "boom town, a pulsing industrial organism that pumped its myriad products through labyrinthine arteries of the greatest of all mass production industries," automobile manufacturing. ${ }^{35}$ While much of this industrial labour was reserved for male workers, women made inroads in related industries. ${ }^{36}$ McGowan's experience mirrored these larger trends, as she took her first formal wage position at the A.C. Spark Plug Factory, a sprawling plant that employed nearly 20,000 workers. ${ }^{37}$

Trouble followed McGowan to Flint, where she found herself working alongside another young girl from Malden. Rumours of McGowan's past resurfaced and led to violent confrontations between herself and her coworkers on the shop floor. ${ }^{38}$ The drama at work compounded problems at her sister's home. Soon after she moved in, Rita's husband began making sexual advances on her. When McGowan refused, she again found herself without a place to stay. Rather than portraying this as a tragic moment (fitting with the "fallen woman" narrative), she frames it as the first time she felt assertive, grown-up, and wise to the world. "It's the first time I felt confidence in myself," she explains. "I wasn't a green kid from the country any more. In the last three months I was learning fast ... I felt too good and too stubborn to marry some jerk like Rita's husband and live a miserable life for the rest of my years." 39 Her rejection of her parents' and sister's lives-which she associated with abuse, poverty, and a stifling moralism-pushed McGowan to look for independence and stability outside the domestic realm. Like many workingclass women who came of age in the first decades of the twentieth century, McGowan began to see wage labour as the key to her own personal independence. ${ }^{40}$ Though she would marry again briefly in 1952 (a marriage she ended after she discovered that her husband had a heroin habit and was stealing money from her to pay for it), McGowan devotes the remainder of her narrative to work-related rather than familial relationships.

Here we begin to see the roots of McGowan's attitudes toward labour, and how they were shaped by illicit economies flourishing in Midwestern cities. McGowan ended up alone, without the support of family or friends, during the heyday of Prohibition. With the passage of the Eighteenth Amendment and the Volstead Act in 1919, vice networks grew across the nation's cities. This was particularly true in states like Michigan, with its close proximity to Canada (where the exportation of liquor was a legal and thriving venture). ${ }^{41} \mathrm{McG}$ cwan's first foray into the illicit economy thus began with bootlegged liquor. After leaving her sister's home, McGowan connected with a young woman named Mary Zborski, who was involved in the Flint "whiskey racket." Their illegal ventures and their relationships with local men landed them in the Flint jail several times, as well as the venereal ward of the city's Hurley Hospital. ${ }^{42}$ Seeking to get out of the "heat," they eventually headed to Peoria, Kansas City, and Chicago, where McGowan learned to cater to the wiles of her customers as a "cigarette girl." ${ }^{3}$ She claims to have briefly worked at Al Capone's Cotton Club, where she cultivated the skill of flirting with customers 
for tips. After about a month, and with gang violence escalating, McGowan returned to Michigan to try to make her way in the wide-open city of Detroit.

Like the auto industry, which transformed Detroit into a bustling bluecollar city, Prohibition shaped the city's cultural life in important ways. The lucrative bootlegging industry aided the growth of prostitution, which operated openly in the city's downtown neighbourhoods. ${ }^{44}$ In 1926, the American Social Health Association (ASHA) commissioned a six-month investigation of vice in the city. It operated in a fashion typical of contemporary anti-vice commissions, deploying undercover agents to assess the extent of the sex trade. Members of the ASHA found the result deeply troubling. The 135-page report details the various forms of solicitation the investigators witnessed, which took place on the streets, and in automobiles, dance halls, call-flats, massage parlours, hotels, and brothels. ${ }^{45} \mathrm{It}$ describes the large number of women who moved to the city in order to work in the illicit trade, as well as the many men of the "labouring class" who openly courted their services. ${ }^{46}$ Investigators were particularly struck by the story of one woman who had moved to Detroit from as far as Mexico (where they had licensed prostitution, the investigator noted) because "Detroit promised better things!" 47 The study concluded that, "the city of Detroit is literally overrun with prostitutes ... From underworld sources the investigators learned that Detroit is still regarded by prostitutes and pimps as one of the best, if not the best, cities in the United States in which to practice their business." 48 This situation, they claimed, was "worse" than in any other American city, noting that, "more violations were discovered in one month in Detroit by three investigators than the same men have been able to uncover in the City of New York in the past three years." 49

The sensational tone of the ASHA report is reflective of its ultimate purpose: to eradicate the "social evil" from the city. Still, its description of the expansive vice industries operating in Prohibition-era Detroit dovetails with McGowan's experience. The visible nature of the trade allowed young women who had few personal contacts in the city to enter the profession relatively quickly. When McGowan first arrived in Detroit, an acquaintance introduced her to several brothel owners. Initially she had a difficult time finding someone willing to hire her, since she was still under the age of twenty-one (and would have brought a felony charge and longer jail sentence if arrested).$^{50}$ Instead of working in a brothel, then, McGowan began by selling her services on the street - the lowest-paid and most dangerous level of the industry. Over the next thirty years, she worked as a streetwalker, in call-flats, and eventually owned her own brothels. Her experience at each level had a profound impact on how she understood the meaning of labour and the place of commercial sex in American society.

\section{Sex Work as Work: Labour and the Sex/Gender System}

Though McGowan continues a largely chronological narrative throughout her memoir, she also begins to structure her anecdotes around political arguments. In 
doing so, McGowan articulates a dual consciousness as both a woman and a member of the working class, an intersectional identity that animates her interpretations of illicit labour. McGowan frames prostitution as a viable choice women made when few other job opportunities were available. According to McGowan, she began selling sex because she "was sick of poverty, sick of being kicked around, and here was a chance to rise in the world..." ${ }^{51}$ In this formulation, this was an economic choice - a rational decision in a stratified capitalist economy where service and other low-wage work were among the few viable options for women. At the same time, McGowan also uncovers the dangers women experienced within the illicit economy itself. These experiences lead her to argue for legalized prostitution, seeing this as one way to address the most egregious hypocrisies of the gender systems that shaped women's lives at mid-century.

Unlike contemporary vice investigations, which focused on prostitution as an aberrant outgrowth of the urban underworld, McGowan frames her memoir as a story about labour. Her narrative focuses on prostitution as a business, one akin to other service industries in the city. She provides detailed descriptions that illuminate the social history of that labour, including how different brothels operated, the amount of money women and madams could charge, and the tactics women used to acquire customers. McGowan describes her houses in language typical of the service industry: in order to be successful, one needed to know her customer; to market an affective experience (beyond sexual pleasure); and to maintain a level of professionalism. The author also describes the laborious process of learning how to ascend in the trade, explaining that it took her five years "of waiting, planning, discouragement, [and] failure" before she was able to open up her own house. McGowan began modestly, working in a call flat with two other women. ${ }^{52}$ At the height of her career, she operated out of the Mohawk Hotel at Temple Street and Third Avenue, where she supervised seven women. ${ }^{53}$ One of the constant realities, given the illegal nature of her business, was the need to move around in order to evade arrest. McGowan claims she moved at least three hundred times over the course of her career, sometimes as often as thirty-five moves in a year. ${ }^{54}$ The mobile nature of the trade meant that interpersonal contacts were crucial. McGowan weaves her own story together with those of other prostitutes and madams she worked with in the local market, a strategy designed to achieve one of her central objectives: to humanize the women who performed sexual labour. If she could portray them as skilled workers_ _ "professionals," in her own wordsshe could challenge common conceptions that these women were simply deviant and disposable.

In creating a vivid picture of the interpersonal relationships essential to vice economies, McGowan maintains that the sex trade-though illegal-was central to the cultural life of Detroit's working-class neighbourhoods. Women and men worked across a wide range of enterprises, with local businesses relying on one another to operate successfully. Speakeasies, bars, movie houses, dance halls, 
and clubs became meeting places for prostitutes and potential johns. Many of the women who worked for McGowan also held positions in the formal economy, selling sex to supplement their fluctuating incomes. Contemporary studies support McGowan's personal anecdotes. The case files of women arrested in Detroit for prostitution between the 1930s and 1950s similarly reveal that their top three occupations outside of prostitution were that of domestic worker, waitress, and factory worker. ${ }^{55}$ Women therefore gained their job experiences in the thriving factories and entertainment districts that made up Detroit's blue-collar neighbourhoods.

Toward this end, McGowan refutes the notion that there was a strict divide between legal and illegal businesses, where the former was acceptable and the latter strictly condemned. Instead, working-class neighbourhoods offered spaces where illicit services could be bought or sold, and where illicit leisure served as both social outlets and forms of money-making. This fluidity became important in the postwar years, as the divide between working-class communities and the middle-class suburbs grew. In the downtown leisure districts, vice allowed men and women to participate in activities that would have been considered far outside the normative bounds in the city's suburban communities. McGowan's clientele reflected this reality:
Although lawyers and doctors and many other professional men may frequent my parlors, the majority of callers are from the working class, the one-hundred-dollar-a-week boy. I charge a fair price, well within the means of the lonely employed worker. My men know they won't be rolled; they don't have to worry about venereal disease: they feel safe in my houses. ${ }^{56}$

Thus, while men from wealthier communities sometimes frequented her houses, the bulk of her business relied on the working-class men who lived in close proximity to the vice districts. She further explained that she worked hard to cultivate loyalty among her customers: "Having steady patrons has been the secret to the success I have had. Very few madams learned that during my long years in the business. They depended on the quick take at high rates. They didn't last long." ${ }^{57}$ Instead, she offered customers services at affordable rates, building a word-ofmouth business through the working men whose money helped keep her in business and the working women who sought alternative forms of employment.

While McGowan argues that commercial sex offered some women the possibility of independence, mobility, and financial gain, this is not a celebratory narrative of commercial vice. Instead, she carefully outlines the risks involved in the trade. McGowan draws parallels between male-dominated legal industries and the control that men exerted in commercial sex. Though women performed the bulk of the labour, they still had to answer to male authorities who worked at higher 
levels. As she explains, "Every madam has two bosses: Mr. Citizen and Mr. X, who represents the rackets. It's like steering a boat between two jagged rocks in an ebb tide and it's not easy. I learned the hard way that I couldn't operate without the O.K. of the racket bosses, so I came through for the racket boys." ${ }^{58}$ In most cases, this included payoffs to local crime bosses, who in turn allowed her to operate within their designated neighbourhoods. ${ }^{59}$ The hardscrabble, street-tough tone McGowan infuses into her writing style reflects these power dynamics. By adopting the persona of the "old-time madam," she presents herself as a powerful force to reckon with, even for the many male competitors she met on a regular basis.

In addition to the growing power of the "racket boys," McGowan describes how the rise of pimping stunted women's ability to exercise a degree of freedom over their working conditions. The author discusses several men she interacted with over the course of her career, portraying them as among the most exploitative and abusive players in the industry. She claims to have lost several close friends to pimps who convinced the women that they would take care of them, but that ended up leaving them alone and destitute. McGowan's framing of the interpersonal relationships that developed within the sex trade speaks to an important element of the industry itself: its reliance on affective labour. Women's positions in the sex trade blurred the lines between the public/private dichotomy, between the professional and the personal, sometimes in problematic ways. This was particularly true of the relationship between pimps and prostitutes. As McGowan writes, "I am often asked why a woman will happily hand over money to an animal who often beats her or who generally deserts her for another prostitute as soon as her looks go. The pimp plays on the very human loneliness she experiences, her wanting to belong to someone who cares." ${ }^{60}$ McGowan similarly recalls a time when she confronted a young woman named Betty about why she stayed with her abusive pimp. "I'll leave that son-of-a-bitch one of these days," Betty explained. "When I think of the money I spend on him, I get mad at myself. But I guess the only reason I keep this pimp around is that when I wake up in the morning and look at him I say to myself that here is one person lower than I am." For McGowan, the constant pressure of being told they were worthless led some women to work for violent male figures. This was not a condition inherent in the act of prostitution itself, but rather a reflection of women's marginalization within the sex trade and within a society that treated them as social pariahs. ${ }^{62}$

McGowan portrays pimping in stark contrast to her own role, claiming that a sense of gender solidarity developed between madams and the women they employed. She draws on collectivist language_ — one that mirrored larger notions of working-class solidarity-in order to justify this relationship. In brothels, she explains, "the girls usually stick together. You better believe it. There is a kind of honor in the group. It is survival for the troupe if they do not betray one another, prison if they do." ${ }^{\prime 3}$ She explains that she paid for regular medical check-ups, and tried to ensure women's safety when possible. In her opening "Appreciation," she 
begins with a "heartfelt thanks to my girls" for enabling her to live a comfortable life. "You are the ones that made me," she declares. On the one hand, the reader could interpret this as McGowan's way of justifying her own position within the sex trade. By calling attention to a sense of gender solidarity, McGowan perhaps obscures her own role in what were unequal-and potentially exploitativehierarchies. This seems, though, to be an oversimplification. In her study of prostitution in New York City during the same era, Elizabeth Clement finds that madams regularly utilized similar descriptions of their role in the sex trade, arguing that it stemmed more from their understanding of normative masculine and feminine roles than from some self-righteous claims on the part of the madams. In this formulation, madams viewed pimps as failed breadwinners, as men who exploited vulnerable women for their own financial gain. Madams, in contrast, saw themselves as more aligned with the image of the female caretaker, thus providing them a moral authority that male pimps lacked. Put simply, "pimps were parasites who ruined women, while madams made mutually profitable business arrangements" with "their girls." ${ }^{4}$ Since McGowan's own position fluctuated within the sex trade_—as she moved from streetwalker to brothel owner then back to selling sex at the end of her story-she likely saw her interests and experiences as closely aligned with the women who worked under her.

Further, McGowan uses this subject-position as the honourable "old time madam" to highlight structural inequalities that began to affect women working in the sex trade by the postwar era. She notes a concerted decline in women's working conditions, one that exacerbated their marginalization in the sex/gender system. As she argues, the rise of pimping correlated with a decline in brothel-style prostitution in the city. The legalization of alcohol in 1933, when coupled with the growing number of women in need of work during the Great Depression, put pressure on brothels that had flourished during Prohibition. Increasingly, there were more women competing in the local market, and many of them were offering services at a cheaper rate through street-based prostitution. As McGowan laments, "Prostitution is a lot different today in some ways from the status it achieved in the thirties." It used to be that,

A very popular girl then could earn with tips over two hundred dollars in a twelve hour period. Of course some of the money went to the madam, some to the racket boys, and a great deal to her pimp, if she had one. The prostitute now makes far less than her older sister of the roaring twenties. She cannot charge quite as much. ${ }^{65}$

Here, McGowan adopts a classic literary style: a nostalgic longing for better days. She fuses her own experiences within a more general cultural memory of the "Roaring Twenties," a time seemingly defined by fast living, economic growth, and 
loosening social mores. Yet, contemporary studies similarly document the negative impact these structural shifts had on working women's lives. As women moved away from brothel-style prostitution, the modicum of protection that brothels offered (including protection from violent johns, the ability to avoid police, and access to medical care) was less common by the postwar years. ${ }^{66}$ In effect, women's earning power, safety, and the ability to rise in the industry deteriorated as street walking became more common.

McGowan identifies two other trends that affected women's work experiences. First, she notes the increasingly pervasive use of heroin among sex workers. Though opium, cocaine, and morphine had been available in the $1920 \mathrm{~s}$ and 1930s, heroin had become the most commonly used drug in the postwar years. This trend was in fact national in scope, as the opening of global trade routes after the Second World War led smugglers to focus their efforts on powdered heroin. ${ }^{67}$ By the early 1950s, Detroit claimed the nation's fourth highest arrest rate for narcotics offences, and local enforcement officials estimated that heroin comprised the vast majority of those arrests. ${ }^{68} \mathrm{McG}$ owan tells of her experiences working alongside women who began using the drug on a regular basis, and the effects this had on their ability to function in the illicit trade. As she notes, "if these women had the bad luck to be addicted to narcotics (and many of them are) or if her pimp is an addict, she is little better than a pauper." ${ }^{69}$ This led to an endless cycle where women often had to work just to keep up with their habits: "Her fix is cut ruthlessly, and sold ruthlessly. 'Credit' is practically unknown. So the whore prostitutes herself, and her boyfriend steals or works the rackets." ${ }^{70}$ Heroin may have given users "a sense of power and well-being," and "put them above and beyond their everyday existence for a short while, at least," but the lasting effects were often devastating. For this reason, McGowan tried to ban drug use from her houses, seeing it as a direct threat to women's ability to perform their jobs and to maintain a level of selfsufficiency. The fact that her second marriage ended so abruptly due to her husband's heroin habit also likely shaped how she viewed the drug: as something that destroyed careers and personal relationships.

The growing popularity of heroin further compounded the third major development that reshaped the illicit trade: the professionalization of urban police forces. McGowan characterizes the interactions between working women and Detroit policemen in the 1920s and 1930s as a game of sorts, one that might result in the inconvenience of a fine or short jail time. Simply keeping pictures of vice agents on hand could be enough to enable her to avoid detection and arrest. McGowan devised other strategies to evade vice statutes, such as leaving the front door of the brothel unlocked so that the police could not levy a "receive and admit" charge against her. If undercover officers let themselves in, she would simply direct the girls to return any cash they had been paid. 'You aren't a prostitute unless you're paid," she explained. "Otherwise, you're just acting like the tens of thousands of juveniles in Detroit, or in the wealthy suburbs." 71 Once again, McGowan draws 
attention to the hypocrisy in criticizing the work performed by prostitutes, noting that the exchange of money is all that separates it from what goes on in "respectable" neighbourhoods.

By the 1950s, the presence of the vice squads became more pronounced and their work more efficient, making McGowan's evasion tactics less effective. As the author described it, prostitutes and madams were "hounded by a much more efficient police," who were eager to detect, fine, and jail women for selling sex. ${ }^{72} \mathrm{~A}$ combination of new technologies (such as fingerprinting, mug shots, and surveillance) provided the police department with better tools to achieve their goals, and urban renewal programs provided a political impetus for more intensive street "clean-ups." The hiring of Vice Squad Inspector Clayton Nowlin in 1940 (and his squad of handpicked cops referred to as "The Untouchables") increased the pressure on working women, as periodic vice raids became more common. ${ }^{73}$ In 1956, McGowan became the subject of one of Nowlin's investigations. "It was all done very fancily, with telephoto lenses, planted spies, and paid informers." As a result, she was arrested, charged, and convicted of "keeping, occupying, and operating a place to be used for prostitution and lewdness." 74 McGowan served three months in the Detroit House of Corrections (DEHOCO), the longest sentence she received during her thirty years working in the city.

In uncovering the working conditions women experienced in the commercial sex trade, McGowan formulates pointed critiques of broader social attitudes that made it possible to treat prostitutes as disposable. Near the end of her story, she circles back to her experiences as a young woman growing up in a small Southern town where religious conservatism was pervasive. She frames her parents' physical abuse and willingness to kick their daughter out of their home, all while claiming to be loving Christians, as her early introduction to moral hypocrisy. Her work in Detroit further compounded her contempt for such values. She expresses disdain for the pious "society ladies" (the "matrons, dripping with jewels and with faces from the beauty parlours waiting to be photographed by the daily news sheets...") who condemned her labour, yet whose husbands often patronized the brothels in the city. McGowan notes that "these holier-than-thou overfed creatures raise their plucked eyebrows at the confessed whore," supposedly unaware that their own husbands help keep such institutions running. ${ }^{75}$

McGowan defends her own moral virtue, not in religious terms, which rang hollow to her, but instead through a play on capitalist rhetoric. In doing so, she reformulates notions of "respectability" that had permeated the language around gender and public space since the late-nineteenth century. McGowan came of age at a time when a woman's status was determined by her ability to exemplify the virtues of thrift, piety, hard work, and self-restraint. This was particularly true in relation to sex and gender codes, which determined the line between the "rough" and "respectable" working class. ${ }^{76}$ Writing in the early-1960s, McGowan instead redefines respectability along the lines of the tax-paying citizen, arguing that her 
(illicit) labour enabled her to participate as a productive member of society. ${ }^{77}$ McGowan reminds readers that the "love money" funnelled into legal channels helped pay for critical community services. ${ }^{78}$ She also outlines her personal economic contributions to the community. One of only two photographs included in Motor City Madam is a copy of the official tax receipts she received from the city over the years. Even after the publication of her memoir, McGowan seems to have continued to cultivate a persona as a benefactor of the local community. On at least one occasion, covered by the Detroit Free Press in 1966, McGowan publicly offered to donate $\$ 500$ to a local family who lost their home in a fire. As she explained to a reporter, "You don't care where the money comes from, do you? As long as it does some good."79 After all, she reminds readers, in America "respectability" had become "mainly a matter of money."

McGowan combines her critiques of economic value, moral hypocrisy, and the dangers of the trade to advocate for legalized prostitution. She frames criminalization as a losing battle in a capitalist system where desire is constantly commodified. "Do away with sex and you'll do away with houses," McGowan explains. "As long as sex survives, men will be heading for the parlors where pretty girls await them and their money. You cannot take this product off the market." Outlawing popular goods and services rarely works, a lesson she believed the country should have learned in the tumultuous Prohibition years. ${ }^{80}$ Prostitution would "vanish," McGowan claimed, in typical Cold War rhetoric, "only with the explosion of the big bomb." 81 In the meantime, cities gave away valuable tax money by suppressing the enduring industry:

The great bulk of our funds went to hoodlums and lawyers, thanks to our righteous laws that 'protect' the public against the oldest profession. The trouble with American thinking in this particular region is that the facts don't matter. A puritan hangover, one of my lawyer friends called it. For every dollar paid in fines to our courts, four or five goes into the pockets of some racket man. By making prostitution legal, the government could build a fine school in every district of every state that is now sending its kids to firetraps or to no schools at all, or to half day [sic] sessions. ${ }^{82}$

By enforcing strict vice codes, city officials enabled a lucrative black market while foregoing any of the economic advantages that legalized prostitution could bring to struggling downtown communities.

More significantly, McGowan challenges the dehumanization that accompanies criminalization, which left women vulnerable to abuse by johns, pimps, and corrupt police officers. Referencing what she had read about European systems, McGowan argues that legalizing prostitution would help curb some of those abuses 
in North American cities. She makes this case in a dramatic fashion in the opening "Appreciation." "I hope," she writes, "that some of you will profit from my experiences-this goes especially for mothers with daughters growing into womanhood. They, I hope, will vote for legalized prostitution in America someday to protect their daughters from the sex-crazed maniacs who walk the city streets." 83 McGowan may have chosen to begin with this sensationalist claim in order to draw readers in, and thus to sell more books. Yet she follows this argument through the narrative, demonstrating repeatedly how the marginal status of prostitutes had a direct impact on their safety and security. "Why should the law and the churches be so anti-prostitution?" she asks. "We have paid our debt to society, and are still paying, and will keep paying until this so-called disgusting, degrading, lowly, and filthy profession is legalized." ${ }^{84}$ Until then, "wrecked young lives is the price we pay..." for continuing to criminalize prostitution. At its heart, McGowan's fundamental critiques foreshadow those of sex work advocates today: those who perform sexual labour are not disposable; their labour has value; and, as a result, they deserve legal protection.

\section{Race, Whiteness, and Marginality in Motor City Madam}

McGowan presents herself as a member of the working class and as a woman navigating a larger patriarchal society, enabling her to formulate pointed political critiques of the sex/gender system. In doing so, she also provides important insight into the complex and contradictory ways that race shaped Detroit's vice economy. Indeed, McGowan engages with race and racial identity from the beginning of her narrative. In the opening lines of the "Appreciation," McGowan tells the readers that she is "part Cherokee Indian ... one of the first Americans here." ${ }^{\prime 5}$ She later describes her parents as hard-working sharecroppers and religious folk, both of whom had Cherokee ancestry. ${ }^{86}$ Yet, despite this early invocation, McGowan begins to shed this identity throughout the remainder of her narrative. As she moves from childhood memories to her adult experiences, she makes only passing reference to what she refers to as her "tough Indian skin" and various "Cherokee proverbs." 7 When she invokes these phrases, she uses them as a way to describe her moral character, usually as strong, proud, or resourceful. While this identity may have been rooted in her family's cultural heritage, it also reads as what historian Philip Deloria describes as "playing Indian," an attempt to create a sense of authenticity by playing on stereotypical notions of indigeneity. ${ }^{88}$ She does not seem to develop a sense of racial consciousness as a Native woman living in the rural South or in the segregated north. Nor does she include any discussion of other people reading her as "mixedrace." The town drama that ensued when rumours spread that her baby was "dark skinned" suggests that local townsfolk expected her baby to reflect her own racial location-discernably white. She instead invokes indigeneity as an internal identity that helped her survive on the tough streets of Detroit, rather than as an external subject-position that affected her status in the local vice networks. 
McGowan's racial location takes on particular significance as she moves from Missouri to Michigan. Her decision to downplay her supposed rural, Cherokee roots may have been strategic; she likely learned quickly that whiteness had a political and economic value in a city increasingly divided by racial lines. McGowan moved to Detroit at a time of considerable demographic change and built her businesses as racial segregation and tensions deepened in the city. As part of the Great Migration that followed the First and Second World Wars, and as part of what James Gregory terms the Southern Diaspora, thousands of African Americans moved from the rural South to cities like Detroit. ${ }^{89}$ As a result, Detroit's African American population doubled, as men and women hoped to escape Jim Crow and find employment in the booming auto town. ${ }^{90}$ Once they arrived, black migrants were met by hostile white communities who created legal barriers that enforced segregation in the city's downtown core. Tensions between black and white residents grew, as they competed for limited housing and jobs. ${ }^{91}$ After the close of the Second World War, racial segregation deepened, as the phenomenon of white flight encouraged white residents to move to nearby suburbs in larger numbers. ${ }^{92}$

Segregation also shaped the city's vice districts, albeit in contradictory ways. In the first decades of the twentieth century, Progressive Era policing practices pushed vice into the growing black communities. ${ }^{93}$ While this was largely done to shield white and middle-class communities from the evils of vice, it also had unintended consequences. The passage of Prohibition in 1919 provided the impetus that helped vice economies grow, thus simultaneously pumping dollars into black neighbourhoods. When McGowan moved to the city, communities like Paradise Valley and the surrounding Black Bottom were home to thriving illicit businesses. Numbers-running, gambling, underground clubs, and other forms of illicit businesses became vital to building economic networks in the city's black communities. In "Cabarets, dance halls, movie theaters, and poolrooms" workers who were "shut out of industrial and white-collar labour, found desperately needed employment in these commercial and illegal forms of leisure." ${ }^{94}$ While the repeal of Prohibition stunted some of this business, vice networks re-emerged in smoky jazz clubs, taxidance halls, and cabarets that opened along Woodward Avenue and in the Twelfth Street Community. As McGowan described Detroit's vice districts in the years after repeal, it was a "time when the pros were pros and pimps were pimps ... High class all the way around ... And, these were the depression days believe it or not." 95 McGowan watched women like Brown Bessie and Mamie Moss run successful brothels, looking to them for insight into how to grow her own business. ${ }^{96}$

Though the repeal of Prohibition did not destroy vice economies, it did facilitate a structural shift along racial and ethnic lines. During the 1920s, African American men were able to ascend to the higher levels of underground economies, particularly in businesses such as numbers running and gambling. The rise of whiteethnic gangs, though, began to displace black players. Several Italian and Jewish gangs had consolidated power in Detroit during Prohibition, selling bootlegged 
liquor and other illegal goods. ${ }^{97}$ After repeal, they focused on gambling, numbers running, narcotics, and prostitution, using violence and intimidation to get others to comply with their demands. ${ }^{98}$ For McGowan, this often meant making payoffs to local crime bosses like Frank Randazzo and Michael Bartello, who in turn allowed her to operate within their designated neighbourhoods. ${ }^{99}$ McGowan includes the story of Joe Fortuno, whom she describes as the typical pimp who worked for the white-ethnic gangs. Fortuno grew up in a well-off Italian-American family, but after getting in to some trouble (including impregnating two "highly proper girlfriends"), he started working for the racket boys. Soon after, he drove a Cadillac, bought "his girls" the finest outfits, and made sure to give to local Italian charities. By connecting with the right ethnic networks, men like Fortuno could rise to the top and make a name for themselves. ${ }^{100}$ In contrast, the African American workers McGowan writes about tended to operate at lower levels of the trade. Mary, a "colored maid," cleaned her houses. ${ }^{101}$ The "colored bellhops" directed customers her way. ${ }^{102}$ The kitchen in one of her higher-end brothels was staffed by "two elderly Negroes" who were aided by "two younger ones." "103 While these positions were crucial to helping McGowan run her businesses, they represented lower paid positions that offered little social mobility.

Racial and ethnic hierarchies also affected the prostitution industry. Increasingly, black women comprised a disproportionate number of women selling sex in Detroit's vice districts, and they were more likely to work as streetwalkers, the lowest and most dangerous level of the trade. As one contemporary study explained, "this percentage [of] white decrease (and corresponding Negro increase) in" streetwalking was, in part, a reflection of the broader labour market, which relegated black women to domestic, unskilled, and service positions. ${ }^{104}$ This went beyond labour segmentation, though. It also reflected a racialized logic that defined beauty and sexual appeal along race and class lines. Another contemporary sociological study, by Glenn Seymour Taylor, notes that although black and white women often worked in the same neighbourhoods off of Woodward Avenue, white women and light-skinned black women were often able to attract higher-paying customers. As Taylor describes, "higher type ... colored girls" sometimes serviced white customers "exclusively," and were able to elicit higher payments than streetwalkers. ${ }^{105}$ Case studies included in the study similarly reveal that the researchers themselves categorized women by race and class. When describing white and white-ethnic women, researchers tended to use positive language about attractiveness, cleanliness, and family "stock." In contrast, they often describe women of colour as unattractive or of low social status. Allie, for example, is described as a "disillusioned and dejected colored lady who looks much older than her 38 years." 106 This is in clear contrast to the description of a white woman like Francis, whom the researchers describe as an "intelligent, attractive, sophisticated" girl who "dresses well" and "could easily be mistaken for a popular co-ed." Millie, whom the researchers claim was typical "of at least half the girls in the racket in Detroit today," summed up 
this dejection, telling the researchers: "I don't know what you want with me; I'm just another nigger whore." 107 In these cases, it becomes clear that distinct racial and class hierarchies shaped not only women's ability to rise in the local trade, but also their own sense of belonging and self-worth.

McGowan's hiring practices similarly suggest that racial markers defined a woman's value in the sex market. In fitting with larger patterns of migration during this era, many of the women who worked for McGowan were themselves Southern migrants who had moved to Detroit from the "impoverished regions of Tennessee, Georgia, and Alabama." As she explained, they "made good whores and they learned to please men much quicker than the Northern girls." 108 Though McGowan hired both black and white women, she portrays white and light-skinned women of colour as the most marketable. When she operated a high-end brothel off North Woodward, for example, McGowan ensured to hire girls who would reflect a broad taste and sexual appeal for her largely white clientele. As she describes her top workers:

\begin{abstract}
Beth Manning was a "blue-grass" girl from Kentucky ... Shirley Jones ... was small and dark, with a tawny skin that seemed to glow with health ... Lois Cumberland [was] just five feet tall and quite slender, she was the most beautiful redhead I have ever seen ... Doris Wilson, a stunning brunette, with eyes of the prettiest green-blue shade, was far and away the wildest of the five ... Last, and most seductive of them all, was Carmen Pollard, an octoroon from Memphis. Her face was a perfect oval, with a matchless skin and soft brown eyes that were incomparable. ${ }^{109}$
\end{abstract}

Like the contemporary sociological studies, McGowan makes it clear that physical traits and cultural markers became a way of defining a woman's value and status. Terms such as "tawny" and "octoroon" (or one-eighth African American) indicate that, though Shirley and Carmen were women of colour, they had light skin and features McGowan felt she could market to her customers. By playing on fantasies of racial and cultural difference-and on the Southern Belle fantasy-McGowan's hiring choices allowed white men to cross the colour line in the discrete comforts of a swanky motel. These interactions allowed white men to find something that perhaps they could not find at home, or in the highly codified dating scenes in the wealthier suburbs. Her hiring patterns thus suggest a clear division between women deemed able to ascend in the trade, and those relegated to streetwalking. Even in integrated vice districts, and in businesses that pushed the strict black/white colour line, whiteness maintained an elevated status.

If McGowan's businesses capitalized on a broader racial order, she also seemed to grapple with the implications of those hierarchies. Though she operated from a privileged position — as a white woman and as a madam—-the author still 
recognized the impact structural racism had on residents in the vice districts. When McGowan criticizes the expansion of policing powers in the city, for example, she makes it clear that this disproportionately affected African American residents. According to the Taylor study, police were more likely to target women in the city's vice districts, where they practiced an "apparent policy ... to discriminate against colored girls." 110 McGowan similarly recounts cases of racialized policing. In one example, she recalls a time police arrested her on a larceny charge. Earlier that day, policemen picked up an African American man named Jabe, who sometimes did "odd jobs" for McGowan. They found him in possession of various items that had been stolen from McGowan's neighbour. Jabe lied to the cops, telling them that McGowan had given him the items. McGowan, who described Jabe as a "decent" guy who brought her girls sandwiches and spaghetti from a nearby restaurant from time to time, followed along with the lie. "They booked me for larceny," she explained. "It was better that way. I could afford to pay the hundred dollar fine they tossed at me but I knew they would throw the book at Jabe. The heat was really on the Negroes at that time."111 This anecdote seems to serve multiple purposes. On the one hand, it proves that McGowan had risen far above her roots as a poor Southern girl. Here she was, able to afford to pay $\$ 100$ and to take a legal rap for a crime she did not commit. Once again, the author seems intent on portraying herself as someone who helped the most marginal, thereby countering the perception that sex workers were dangerous and unwanted members of the community. It also shows that McGowan was acutely aware of the racial order that permeated Detroit by the postwar period. She understood that her position as a white woman provided her a level of protection not afforded to men like Jabe. As a black man whose employment status was precarious, he was precisely the type of community member who bore the brunt of Detroit's intensified policing practices.

McGowan also invokes racialized language in order to make the case for legalized prostitution, thereby framing marginality as a status defined along multiple lines. The fact that black women began to comprise the majority of sex workers at the very time in which the industry became more difficult and dangerous, was not lost on McGowan. The author draws explicit parallels between racial and sexual slavery, using the comparison as a way to criticize the structural inequalities built into the local sex market. "What else would you call this but slavery," McGowan asks. "Did the Negro slaves in the Old South ever see their money? Neither did the prostitute." The author's strategy reflects a longer rhetorical tradition within both the labour movement and middle-class reform movements of drawing comparisons between chattel slavery and exploitative labour conditions. ${ }^{112}$ Like these earlier arguments, McGowan invokes slavery as a way to make a moral argument that women's oppression was all-encompassing and their paths out were limited. The author takes this a step further, fusing her criticism of women's exploitation in the illicit economies with the language of justice and rights emerging in the 1960s. The final two lines of her book invoke the urgency and immediacy of her argument: 
"Talk about Civil Rights! These poor whores should have marched on Washington if anyone ever did!" These last words leave the reader with a more militant assertion of working women's rights, one that reflected a broadening discussion about power and protest that permeated Detroit by the early 1960s. By drawing on the language of civil rights, McGowan reinforces her argument that the most marginal womenblack and white - deserved a voice and legal protection in order to save them from an inevitable decline in an exploitative industry.

Motor City Madam, like all personal narratives, forces the reader to grapple with the complicated subjectivities people create as they tell their own histories. This is particularly evident when read through the lens of race. McGowan's descriptions of Detroit's vice districts make it clear that the broader racial and ethnic lines that shaped formal forms of labour in Detroit also emerged within informal economies. McGowan herself capitalized on those divisions. Shedding any outward invocations of her perceived Cherokee heritage, McGowan functioned as a white madam whose brothels hired women according to racial markers. Even in the integrated vice districts, whiteness held both economic and cultural capital, which relegated women and men of colour to the lower-paid positions in vice industries. Yet, though she operated within the confines of the city's racial codes, McGowan also began to develop explicit critiques of those very structures. It becomes clear as she traces her life story-which begins in the Jim Crow South and ends in the segregated north-that McGowan recognized the ways in which racial codes undergirded larger systems of exploitation. Whether through her recounting of her mother's treatment of Ruth in her childhood, through law enforcement's treatment of black residents in Detroit's downtown neighbourhoods, or through the hierarchical structures that relegated black women to the bottom of the sexual economy, McGowan became openly critical of efforts to enforce stark black/white colour lines. When read alone, McGowan's equation of prostitution with slavery, and her invocation of civil rights protests, initially seems cursory and uncritical. When set in the broader context of her historical experiences, these in fact fit with her larger political objectives. McGowan's narrative reads as one woman's struggle, however imperfectly, to understand the multiple forces that came together to define marginality in American society at mid-century. For the author, gender, class, and racial markers worked in tandem to determine one's ability to succeed in the tough world of Detroit's vice districts.

\section{Conclusion}

On its surface, Motor City Madam seems an unlikely labour history. Both the subject and its author fall far outside of what many at the time of its publication would have associated with labour or a working-class identity in a blue-collar city like Detroit. It is not the story of labour unions, organizing, or the factory floor. Yet McGowan's narrative reveals a story of a woman who saw herself as closely integrated into the working-class community that she came to adopt as her own. 
McGowan's first-hand account details the social history of illicit forms of work as they developed between the 1920s and 1960s. Her narrative also reveals how McGowan cultivated a working-class and feminist subjectivity through her experiences in the city's vice districts. Weaving together themes of migration, poverty, and inequality, her work draws explicit parallels between licit and illicit forms of labour in industrial America, further pushing labour historians to consider the ways in which formal and informal economies have been deeply intertwined in the modern American past.

McGowan's autobiography is not a salacious story focused on the sexual exploits of a prostitute, perhaps to the disappointment of some of its readers. Instead, the author tells her personal history in service of a larger political objective: advocating for expanded rights for women who made a living selling sex. Prior to the development of a widespread feminist movement that challenged gender and sexual inequalities in the country, McGowan articulates a pointed critique of the sex/gender system that developed in the middle decades of the twentieth century. Her work is critical of what she sees as the most dangerous trends developing in the sex trade, which included the growing prominence of pimps, the exploitation women faced from higher-ups, increasing drug use, and the intensification of policing in downtown neighbourhoods that took place by the postwar period. These dangers, McGowan argues, were compounded by the illegal status of prostitution itself. As a result, much like sex worker advocates today, McGowan pushes for changes to legal codes that actually left women more vulnerable to that very exploitation. Drawing on the language of capital and productivity, McGowan makes the case that women who worked in the trade contributed to the cultural and economic life of working-class communities and were deserving of protection under the law, not punishment by it.

Motor City Madam also provides important insight into the contradictory roles that race played in the city's vice districts. Though McGowan initially identifies herself as mixed race, she largely sheds this positioning as she moves to the segregated city of Detroit. The author seems to learn quickly that whiteness held an important social status in a city whose demographic makeup was in flux. McGowan's own businesses reflected the broader racial and ethnic lines that developed in the city, wherein white and white-ethnic workers could ascend to higher levels of the trade. Black workers, and especially black women, were often relegated to the lowest levels of the economic order. At the same time, McGowan's autobiography forces us to grapple with the complicated nature of subjectivity and self-identity. For while the author seems to have capitalized on and worked within these broader racial codes, she also becomes openly critical of them. Increasingly, by the end of her narrative, McGowan makes clear that she saw class, race, and gender inequalities as mutually reinforcing. While her political critiques are most forceful in relation to the gender/sex system, the author also makes clear that race and class could further compound a woman's subordinate status. Overall, 
McGowan's narrative reads as the author's attempt to understand the roots and causes of marginality, and in doing so, to provide explicit critiques of the structural lines that relegated some women to the margins of American society.

Autobiographies, as Barrett and Roediger argue, do not represent "the unmediated story of a person's actual experience, but rather a constructed narrative full of conscious and unconscious choices on the part of its author." As such, "they are shaped by the conditions under which they were produced and the goals they were intended to achieve..."113 Motor City Madam reflects both the purposeful political objectives of its author, and the cultural environment in which that political vision was formed. In tracing how McGowan constructs her own subjectivity and her own position in Detroit's vice economies, we can better understand how some women experienced illicit forms of labour. Her text provides a useful case study of the ways in which historians can utilize autobiographies in order to access a sense of working-class subjectivity that emerges within decidedly illicit forms of labour. It also enables us to contextualize the official records of police departments, courts, vice commissions, and other state sources in order to tease out the various ways that individuals experienced those state apparatuses. By analyzing the author's intention, rhetoric, and subject-position, autobiographies allow for a fuller exploration of the contested ways in which working women experienced the enactment of state policies and legal codes on a regular basis. A critical reading of these texts can help us piece together not just the subjects of working-class history, but also subjectivities they laid claim to. 


\section{NOTES}

${ }^{1}$ Helen McGowan, Motor City Madam (New York: Pageant Press, 1964).

${ }^{2}$ Jennifer Jensen Wallach, Closer to the Truth than Any Fact: Memoir, Memory, and Jim Crow (Athens: University of Georgia Press, 2010), 5.

${ }^{3}$ James Barrett and David Roediger, History from the Bottom Up and the Inside Out: Ethnicity, Race, and Identity in Working-Class History (Durham: Duke University Press, 2017), 1.

${ }^{4}$ Exceptions on illicit forms of work in Detroit include Victoria Wolcott, Remaking Respectability: African American Women in Interwar Detroit (Chapel Hill: The University of North Carolina Press, 2001); Holly M. Karibo, Sin City North: Sex, Drugs, and Citizenship in the Detroit-Windsor Borderlands (Chapel Hill: The University of North Carolina Press, 2015); Steven Meyer, Manhood on the Line: Working-Class Masculinities in the American Heartland (Chicago: University of Illinois Press, 2016), ch. 2. For literature that examines women's roles in illicit economies in other cities or regions, see Mary Murphy, "Bootlegging Mothers and Drinking Daughters: Gender and Prohibition in Butte, Montana," American Quarterly 46, no. 2 (June 1994): 174-194; Elaine Carey, Women Traffickers: Mules, Bosses, and Organized Crime (Albuquerque: University of New Mexico Press, 2014); LaShawn Harris, Sex Workers, Psychics, and Numbers Runners: Black Women in New York City's Underground Economy (Champaign: University of Illinois Press, 2016). On women and the labour movement in North America, see: Ruth Milkman, ed., Women, Work, and Protest: A Century of US Women's Labor History (New York: Routledge, 1985); Elizabeth Faue, Community of Suffering and Struggle (Chapel Hill: The University of North Carolina Press, 1991); Ruth A. Frager and Carmela Patrias, Discounted Labour: Women Workers in Canada, 1870-1939 (Toronto: University of Toronto Press, 2005); Alice Kessler-Harris, Gendering Labor History (Urbana: University of Illinois Press, 2007).

${ }^{5}$ In fusing labour history and the history of sexuality, historians have increasingly argued that working-class history has a sexuality, and that sexual and gender ideals are deeply embedded in class structures. See: Elizabeth Kennedy and Madeline Davis, Boots of Leather, Slippers of Gold: The History of a Lesbian Community (New York: Routledge, 1993); Mary E. Odem, Delinquent Daughters: Protecting and Policing Adolescent Female Sexuality in the United States, 1885-1920 (Chapel Hill: University of North Carolina Press, 1995); Ava Baron and Eileen Boris, "The Body' as a Useful Category for Working-Class History," Labor: Studies in Working-Class History of the Americas, 4, no. 2 (2007): 23-43; Meyer, Manhood on the Line.

${ }^{6}$ Ine Vanwesenbeeck, "Sex Work Criminalization Is Barking Up the Wrong Tree," Archives of Sexual Behavior 46, no. 6 (2017): 1631-1640. See also: Amalia L. Cabezas, "Between Love and Money: Sex, Tourism, and Citizenship in Cuba and 
the Dominican Republic," Signs 29, no. 4 (Summer 2004): 987-1015; Melinda Chateauvert, Sex Workers Unite: A History of the Movement from Stonewall to Slutwalk (Boston: Beacon Press, 2014); Gillian Abel et al., eds. Taking the Crime Out of Sex Work: New Zealand Sex Workers' Fight for Decriminalization (Bristol: University of Bristol Press, 2010); Kamala Kempadoo and Jo Doezema, eds., Global Sex Workers: Rights, Resistance, and Redefinition (New York: Routledge, 1998).

${ }^{7}$ McGowan uses the terms "prostitute" and "madam" in her text, so I have chosen to employ these throughout the essay in order to remain consistent with the terminology of the period.

${ }^{8}$ On the salacious side, see: Curt Gentry, The Madams of San Francisco (Garden City, NY: Doubleday, 1964); James R. Gray, Red Lights on the Prairies (Toronto: Macmillan of Canada, 1971); Douglas McDonald, The Legend of Julia Bulette and the Red Light Ladies of Nevada (Las Vegas: Nevada Publications, 1980); Lael Morgan, Good Time Girls of the Alaska-Yukon Gold Rush, $2^{\text {nd }}$ ed. (Kenmore, WA: Epicenter Press, Inc., 1999). On early reform movements: John C. Burnham, "Medical Inspection of Prostitutes in America in the Nineteenth Century," Bulletin of the History of Medicine 45 (May 1971): 203-218; Barbara Meil Hobson, Uneasy Virtue: The Politics of Prostitution and the American Reform Tradition (New York: Basic Books, Inc., 1987).

${ }^{9}$ On the Progressive Era and Western communities, see: Roy Lubove, "The Progressives and the Prostitute," The Historian 24, no. 3 (May 1962): 308-333; Egal Feldman, "Prostitution, the Alien Woman, and the Progressive Imagination, 1910-1915," American Quarterly 19, no. 2 (Summer 1967): 192-206; John C. Burnham, "The Progressive Era Revolution in American Attitudes Towards Sex," Journal of American History 59, no. 4 (March 1973): 885-908; Thomas Connelly, The Response to Prostitution in the Progressive Era (Chapel Hill: University of North Carolina Press, 1980); Marion Goldman, Gold Diggers and Silver Miners: Prostitution and Social Life on the Comstock Lode (Ann Arbor: University of Michigan Press, 1981); Anne M. Butler, Daughters of Joy, Sisters of Mercy: Prostitution in the American West, 1865-1890 (Urbana: University of Illinois Press, 1985); Benson Tong, Unsubmissive Women: Chinese Prostitutes in Nineteenth-Century San Francisco (Norman: University of Oklahoma Press, 1994); Barbara Antoniazzi, The Wayward Woman:

Progressivism, Prostitution, and Performance (Lanham, MD: Fairleigh Dickson University Press, 2014); Ruth Rosen, The Lost Sisterhood: Prostitution in America, 1900-1918 (The Johns Hopkins University Press, 1983); Kathy Peiss, Cheap Amusements: Working Women and Leisure in Turn-of-the-Century New York (Philadelphia: Temple University Press, 1986); Elizabeth Clement, Love for Sale: Courting, Treating and Prostitution in New York City (Chapel Hill: University of North Carolina Press, 2006). Much of the North American scholarship has been influenced by Judith Walkowitz's groundbreaking study on Victorian England, Prostitution and Victorian Society: Women, Class, and the State (Cambridge: Cambridge University Press, 1980). 
${ }^{10}$ Timothy J. Gilfoyle, "Prostitutes in the Archives: Problems and Possibilities of Documenting the History of Sexuality in the Archive," American Archivist 57 (Summer 1994): 514-527. Paul Gootenberg, "Talking Like a State: Drugs, Borders, and the Language of Control," in Illicit Flows and Criminal Things: States, Borders, and the Other Side of Globalization, eds. Willem van Schendel and Itty Abraham (Bloomington: Indiana University Press, 2005), 101.

${ }^{11}$ Ruth Rosen and Sue Davidson, eds., The Maimie Papers (Old Westbury, NY: The Feminist Press, 1977), xiv.

${ }^{12}$ Gilfoyle, "Prostitutes in the Archives," 523. Emphasis added.

${ }^{13}$ Shari Benstock, ed., The Private Self: Theory and Practice of Women's Autobiographical Writings (Chapel Hill: University of North Carolina Press, 1988); Laura Marcus, Auto/biographical Discourses: Theory, Criticism, and Practice (Manchester: Manchester University Press, 1994); Ann Goldman, Take my Word: Autobiographical Innovations of Ethnic American Working Women (Berkeley: University of California Press, 1996); Felicity Nussbaum, The Autobiographical Subject: Gender and Ideology in Eighteenth-Century England (Baltimore: The Johns Hopkins University Press, 1989).

${ }^{14}$ Barrett and Roediger, History from the Bottom Up and the Inside Out, 3-4.

${ }^{15}$ Wayne E. Fuller, Morality and the Mail in Nineteenth-Century America (Champaign: University of Illinois Press, 2003); John D'Emilio and Estelle B. Freedman, Intimate Matters: A History of Sexuality in America, $2^{\text {nd }}$ ed. (Chicago: The University of Chicago Press, 1997), ch. 7.

${ }^{16}$ In 1919, for example, when Harper \& Brothers published Madeline, a memoir of a former prostitute, the press was charged with a misdemeanour for violating New York State penal law prohibiting the distribution of "any obscene, lewd, lascivious, filthy, indecent or disgusting book." The court found the press guilty, issued a $\$ 1,000$ fine, and barred the book's further publication. Geralyn Strecker, "Reading Prostitution in American Fiction, 1893-1917," (PhD diss., Ball State University, 2001), 47-48.

${ }^{17}$ Alan Durant, Meaning in the Media: Discourse, Controversy, and Debate (Cambridge: Cambridge University Press, 2010), 220.

${ }^{18}$ Nancy J. Peters, "Milestones of Literary Censorship," in Howl on Trial: The Battle for Free Expression, eds. Bill Morgan and Nancy J. Peters (San Francisco: City Lights Books, 2006), 5; Jennifer Worley, "The Mid-century Pulp Novel and the Imagining of Lesbian Community," in Invisible Suburbs: Recovering Protest Fiction in 1950s United States, ed. Josh Lukin (Jackson: University of Mississippi Press, 2008), 104-123; Kaye Mitchell, “Who is She?' Identities, Intertextuality and Authority in Non-Fiction Lesbian Pulp of the 1950s," in Queer 1950s: Rethinking Sexuality in the Postwar Years, eds. Heike Bauer and Matt Cook (New York: Palgrave Macmillan, 2012), 150-166.

${ }^{19}$ Howard A. Sullivan, "Vanity Press Publishing," Library Trends 7 no. 1 (1958): 
111; Nancy Derringer, "How an Entrepreneurial Woman Draws Inspiration from Legendary Brothel,” Bridge Magazine, February 8, 2017, http:/ /www.crainsdetroit.com/article/20170208/NEWS/170209839/how-an-entrepreneurialwoman-draws-inspiration-from-legendary-brothel (accessed April 9, 2018).

${ }^{20}$ Derringer, "How One Businesswoman."

${ }^{21}$ McGowan, Motor City Madam, Forward.

${ }^{22}$ Monique Wittig, "One is Not Born a Woman," in Lesbian and Gay Studies Reader, eds. Henry Abelove, Michele Aina Barale, and David M. Halperin (New York: Routledge, 1993), 103.

${ }^{23}$ Christy Rishoi, From Girl to Woman: American Women's Coming-of-Age Narratives (Albany: SUNY Press, 2003), 25.

${ }^{24}$ Betty Friedan, The Feminine Mystique (New York: W.W. Norton \& Co., 1963).

${ }^{25}$ McGowan, Motor City Madam, 87.

${ }^{26}$ Ibid., 3.

${ }^{27}$ Ibid., 4.

${ }^{28}$ Ibid., 2, 4.

${ }^{29}$ McGowan, Motor City Madam, 10.

${ }^{30}$ Ibid., 9.

31 Ibid.

${ }^{32}$ Peggy Pascoe, What Comes Naturally: Law and the Making of Race in America (Oxford: Oxford University Press, 2009), 102.

${ }^{33}$ McGowan, Motor City Madam, 11.

${ }^{34}$ Gordon Young, Teardown: Memoir of a Vanishing City (Berkeley: University of California Press, 2013), 48.

${ }^{35}$ David L. Kennedy, Freedom from Fear: The American People in Depression and War, 1929-1945 (New York: Oxford University Press, 1999).

${ }^{36}$ Wayne A. Lewchuck, "Men and Monotony: Fraternalism as a Managerial Strategy," in Women and the Economy: A Reader, eds. Ellen Mutari and Deborah M. Figart (New York: Routledge, 2003), 68.

${ }^{37}$ Young, Teardown, 48.

${ }^{38}$ Historians have traced the ways in which masculine violence shaped the culture of the auto industries. See: Meyer, Manhood on the Line; Jeremy Milloy, Blood, Sweat, and Fear: Violence at Work in the North American Auto Industry, 1960-1980 (Champaign: University of Illinois Press, 2017).

39 McGowan, Motor City Madam, 14.

${ }^{40}$ As Alice Kessler Harris argues, wage work provided working-class women with a path toward independence, which she defined as "women's attempt to achieve 
without familial constraints.” Alice Kessler Harris, Gendering Labor History (Chicago: University of Illinois Press, 2007), 118. On wage labour and independence, see also: Nan Enstad, Ladies of Labor, Girls of Adventure: Working Women, Popular Culture, and Labor Politics at the Turn of the Twentieth Century (New York: Columbia University Press, 1999); Lara Vapnek, Breadwinners: Working Women and Economic Independence (Chicago: University of Illinois Press, 2009). ${ }^{41}$ Dan Malleck, "An Innovation from Across the Line: The American Drinker and Liquor Regulation in Two Ontario Border Communities, 1927-1944," Journal of Canadian Studies/Revue d'études canadiennes, 41, no. 1 (2007) 151-171; Stephen Schneider, Iced: The Story of Organized Crime in Canada (Mississauga: John Wiley \& Sons, Ltd., 2009); Stephen T. Moore, Bootleggers and Borders: The Paradox of Probibition on a U.S.-Canada Borderland (Lincoln: University of Nebraska Press, 2014).

${ }^{42}$ McGowan, Motor City Madam, 17-20.

43 Ibid., 24-25.

44 "Prohibition in Detroit: How the City Has Benefitted," The Butte Daily Bulletin, February 17, 1919, 2; "What Ousting of Booze from the Big City Made Public," The Bemidji Daily Pioneer, February 15, 1919, 1; "Does Prohibition Really Prohibit? What Fifty Business Men Say," The Evening World, March 6, 1922, 4; "CanadaDetroit Rum Traffic Flourishes," The Seattle Star, Oct. 29, 1921, 5; “Ontario Orders Border Rum Curb," Evening Star, June 1, 1928, 7.

45 "Report on Prostitution, the Police, the Law, and the Courts," 1, Box 099, Folder 09: Legal and Protective Measures, Surveys, Detroit, American Social Health Association Records, 1905-1990 (SW 45), Social Welfare History Archives, University of Minnesota Libraries, Minneapolis, MN [hereafter SWHA]. ${ }^{46}$ Ibid., 4.

${ }^{47}$ Ibid., 13. It is not wholly surprising to find a Mexican woman among the interviewees of the vice investigation. This reflected a more general migration of Mexicans into the city during the 1920s. Zaragosa Vargas, "Life and Community in the 'Wonderful City of the Magic Motor': Mexican Immigrants in 1920s Detroit," Michigan Historical Review 15 (Spring 1989): 45-68.

48 Ibid., 11-13.

${ }^{49}$ Ibid., 11.

${ }^{50}$ Under 15471, Section 197 of the Michigan penal codes, "Keeping House of Ill-Fame or Inducing Women to Enter, Etc., For Purpose of Prostitution,” a madam could be charged with a felony, sentenced to state prison for up to five years, and fined $\$ 1,000$. Michigan, Laws of Michigan Relating to Women, $3^{\text {td }}$ ed. (Lansing: The Library, 1926), 176.

${ }^{51}$ McGowan, Motor City Madam, 35.

52 Ibid., 47-48. 
${ }^{53}$ Ibid., 75.

54 Ibid., 52, 56.

${ }^{55}$ Virginia Sobotka, "A Comparative Study of Prostitution: Trends in the Social Characteristics of the 'Street-Walking' Prostitute from 1935 to 1957,' (MA thesis, Wayne State University, 1961), 41.

${ }^{56}$ McGowan., 153.

${ }^{57}$ Ibid., 56.

${ }^{58}$ Ibid., 68.

${ }^{59}$ United States Senate, Committee on Government Operations, Permanent Subcommittee on Investigations, Organized Crime and Illicit Traffic in Narcotics (Washington: US Government Printing Office, 1963), 452-453.

${ }^{60}$ McGowan, Motor City Madam, 77.

${ }^{61}$ Ibid., 37.

${ }^{62}$ This is in direct contrast to the views of some feminist scholars in the 1970s and 1980s, who argued that prostitution itself was the embodiment of patriarchal exploitation. Jane Scoular, "The 'subject' of prostitution: Interpreting the discursive, symbolic, and material position of sex/work in feminist theory," Feminist Theory 5, no. 3 (2004): 343.

${ }^{63}$ McGowan, Motor City Madam, 135.

${ }^{64}$ Clement, Love for Sale, 200-201.

${ }^{65}$ McGowan, Motor City Madam, 79.

${ }^{66}$ Karibo, Sin City North, 39.

${ }^{67}$ Eric C. Schneider, Smack: Heroin and the American City (Philadelphia: University of Pennsylvania Press, 2008), ch 1.

${ }^{68}$ United States Senate, Committee on the Judiciary, Illicit Narcotics Traffic

(Washington: US Government Printing Office, 1956), 28.

${ }^{69}$ McGowan, Motor City Madam, 79.

${ }^{70}$ Ibid., 79.

${ }^{71}$ Ibid., 64.

${ }^{72}$ Ibid., 79.

${ }^{73}$ Nowlin served as the head of the Vice Unit from 1940 to 1958. "Nowlin Quits, Hoods Happy," Detroit News, January 7, 1958.

${ }^{74}$ McGowan, Motor City Madam, 164-165.

75 Ibid., 67.

${ }^{76}$ Wolcott, Remaking Respectability, 5.

${ }^{77}$ Sparrow argues that this notion of "fiscal citizenship" was rooted in the 
economic shifts required during the Second World War. Lizabeth Cohen further demonstrates that the concept of the "citizen consumer" continued to grow in the aftermath of the war. See James T. Sparrow, "Buying Our Boys Back: The Mass Foundations of Fiscal Citizenship in World War II," Journal of Policy History 20, no. 2 (2008): 266; Lizabeth Cohen, A Consumer's Republic: The Politics of Mass Consumption in Postwar America (New York: Vintage Books, 2003).

${ }^{78}$ McGowan, Motor City Madam, 2.

79 “A Grateful Family Says 'Thank you'," Detroit Free Press, October 26, 1966, 4.

${ }^{80}$ McGowan, Motor City Madam, 152.

${ }^{81}$ Ibid., 156.

${ }^{82}$ Ibid., 75.

${ }^{83}$ Ibid., "Appreciation."

${ }^{84}$ Ibid., 190. Emphasis added.

85 Ibid.

${ }^{86}$ Ibid., 3.

${ }^{87}$ Ibid., 15.

${ }^{88}$ Philip J. Deloria, Playing Indian (New Haven: Yale University Press, 1998).

${ }^{89}$ James N. Gregory, The Southern Diaspora: How the Great Migration of Black and White Southerners Transformed America (Chapel Hill: The University of North Carolina Press, 2005), 12-14.

${ }^{90}$ Sugrue, The Origins of the Urban Crisis, 33.

${ }^{91}$ Joe T. Darden and Richard W. Thompson, Detroit: Race Riots, Racial Conflict, and Efforts to Bridge the Racial Divide (Lansing: Michigan State University Press, 2013), 30 .

${ }^{92}$ Heather Ann Thompson, Whose Detroit? Politics, Labor, and Race in a Modern American City (Ithaca: Cornell University Press, 2001), 26.

${ }^{93}$ Kevin Mumford, Interzones: Black/White Sex Districts in Chicago and New York in the Early Twentieth Century (New York: Columbia University Press, 1997), 20.

${ }^{94}$ Wolcott, Remaking Respectability, 93.

${ }^{95}$ McGowan, Motor City Madam, 188.

96 Ibid., 51.

${ }^{97}$ Mathew Lawrence Daley, "City of Mass Production: Building, Managing, and Living in Detroit, America's First Automobile Metropolis, 1920-1933,” (PhD diss., Bowling Green State University, 2004), 80-84.

${ }^{98}$ Estes Kefauver, The Kefauver Committee Report on Organized Crime (New York: Didier, 1951), 174-175. 
${ }^{99}$ United States Senate, Committee on Government Operations, Permanent Subcommittee on Investigations, Organized Crime and Illicit Traffic in Narcotics (Washington: US Government Printing Office, 1963), 452-453.

${ }^{100}$ McGowan, Motor City Madam, 81-82.

101 Ibid., 71.

102 Ibid., 51.

103 Ibid., 113.

104 Sobotka, "A Comparative Study," 11.

105 Glenn Seymour Taylor, "Prostitution in Detroit," (PhD diss., University of Michigan, 1933), 13.

106 Ibid., 124.

107 Ibid., 132.

108 McGowan, Motor City Madam, 49.

${ }^{109}$ Ibid., 111-112.

110 Taylor, "Prostitution in Detroit," 8.

111 McGowan, Motor City Madam, 59-60.

112 Mara L. Keire, "The Vice Trust: A Reinterpretation of the White Slave Trade Scare in the United States, 1907-1917," Journal of Social History 35, no. 1 (Fall 2001): 9.

${ }^{113}$ Barrett and Roediger, History from the Bottom Up, 35-36. 